\title{
Current perspectives on the use of intravenous recombinant tissue plasminogen activator (tPA) for treatment of acute ischemic stroke
}

This article was published in the following Dove Press journal:

Vascular Health and Risk Management

24 February 2014

Number of times this article has been viewed

\author{
Sherita N Chapman' \\ Prachi Mehndiratta' \\ Michelle C Johansen' \\ Timothy L McMurry ${ }^{2}$ \\ Karen $C$ Johnston ${ }^{1,2}$ \\ Andrew M Southerland ${ }^{1,2}$ \\ 'Department of Neurology, University \\ of Virginia, Charlottesville, VA, \\ USA; '2Department of Public Health \\ Sciences, University of Virginia, \\ Charlottesville, VA, USA
}

\begin{abstract}
In 1995, the NINDS (National Institute of Neurological Disorders and Stroke) tPA (tissue plasminogen activator) Stroke Study Group published the results of a large multicenter clinical trial demonstrating efficacy of intravenous tPA by revealing a $30 \%$ relative risk reduction (absolute risk reduction 11\%-15\%) compared with placebo at 90 days in the likelihood of having minimal or no disability. Since approval in 1996, tPA remains the only drug treatment for acute ischemic stroke approved by the US Food and Drug Administration. Over the years, an abundance of research and clinical data has supported the safe and efficacious use of intravenous tPA in all eligible patients. Despite such supporting data, it remains substantially underutilized. Challenges to the utilization of tPA include narrow eligibility and treatment windows, risk of symptomatic intracerebral hemorrhage, perceived lack of efficacy in certain high-risk subgroups, and a limited pool of neurological and stroke expertise in the community. With recent US census data suggesting annual stroke incidence will more than double by 2050 , better education and consensus among both the medical and lay public are necessary to optimize the use of tPA for all eligible stroke patients. Ongoing and future research should continue to improve upon the efficacy of tPA through more rapid stroke diagnosis and treatment, refinement of advanced neuroimaging and stroke biomarkers, and successful demonstration of alternative means of reperfusion.
\end{abstract}

Keywords: IV tPA, rtPA, t-PA, rt-PA, cerebrovascular disease, cerebrovascular accident

\section{Introduction}

In 1995, the NINDS (National Institute of Neurological Disorders and Stroke) tPA (tissue plasminogen activator) Stroke Study Group published the results of a large multicenter clinical trial demonstrating efficacy of intravenous (IV) tPA in acute ischemic stroke (AIS). ${ }^{1}$ With these practice-changing results, tPA was approved by the US Food and Drug Administration (FDA) for the treatment of AIS and endorsed by the guideline committees of the American Heart Association/American Stroke Association (AHA/ASA), ${ }^{2}$ the American Academy of Neurology (AAN), ${ }^{3}$ and recently by the American College of Emergency Physicians (ACEP). ${ }^{4}$

Although an abundance of research and clinical data has supported the findings from the original NINDS trial, tPA in the acute stroke setting remains substantially underutilized. ${ }^{5,6}$ Stemming from an original series of debates published shortly after tPA approval, ${ }^{7-10}$ apprehension still exists that risks may outweigh benefits in a large number of stroke patients, violating the code of "primum non nocere (first do no harm)." 11 In the United States, tPA remains the only FDA-approved drug treatment
Correspondence: Andrew M Southerland Department of Neurology, University of Virginia,

Charlottesville, VA 22908, USA

Email as5ef@hscmail.mcc.virginia.edu 
for AIS. Therefore, addressing these decades-old controversies continues to hold strong relevance for clinical practice to this day. In this review article, we will highlight many of the debated issues, relevant research, and current perspectives concerning the use of IV tPA for treatment of AIS. The scope of this review will not cover alternative thrombolytics (eg, urokinase and tenecteplase) or intra-arterial administration of tPA. This review will also not address other endovascular therapies unless specifically relevant to the current use of IV tPA. ${ }^{12-14}$

\section{Seminal clinical trials of IV tPA in stroke}

In the early 1990s, a group of investigators began translating preclinical data to the earliest human trials of tPA in AIS to verify dosing, mechanism of action, and safety profile for stroke thrombolysis. ${ }^{15-18}$ Shortly after these early studies, several large randomized, placebo-controlled, double-blinded trials commenced to determine the safety and efficacy of tPA in AIS (Table 1). ${ }^{1,19,20}$ In 1993, the ATLANTIS (Alteplase Thrombolysis for Acute Noninterventional Therapy in Ischemic Stroke)-A trial was halted due to increased risk of symptomatic intracerebral hemorrhage ( $\mathrm{sICH})$ in the 5-6-hour window from stroke onset; unfortunately, interim enrollment fell short of demonstrating any efficacy up to 5 hours. ${ }^{19}$

In 1995, the landmark NINDS tPA study results were published (including Parts I and II), establishing efficacy between 0 and 3 hours from stroke onset by revealing a 30\% relative risk reduction (absolute risk reduction 11\%-15\%) compared with placebo at 90 days in the likelihood of having minimal or no disability. Benefit was compared against a significantly increased risk of $\mathrm{sICH}$ in the tPA group

Table I Early prospective randomized clinical trials of intravenous tPA in acute ischemic stroke

\begin{tabular}{|c|c|c|c|c|}
\hline $\begin{array}{l}\text { Study (publication } \\
\text { year) }\end{array}$ & $\begin{array}{l}\text { Treatment } \\
\text { group }\end{array}$ & $\begin{array}{l}\text { Time window } \\
\text { (median hours) }\end{array}$ & Primary analysis results* & Safety results** \\
\hline $\begin{array}{l}\text { NINDS tPA study - } \\
\text { Part I (1995)' }\end{array}$ & tPA $0.9 \mathrm{mg} / \mathrm{kg}$ & 3 hours $(1.5)$ & $\begin{array}{l}\text { No difference in early clinical } \\
\text { improvement ( }>4 \text { point decrease } \\
\text { in NIHSS or complete resolution) } \\
\text { (tPA } 47 \% \text { versus placebo } 39 \% \text {; } \\
\text { RR I.2 }[\mathrm{Cl} 0.9-1.6 ; P=0.2 \mathrm{I}] \text { ) }\end{array}$ & $\begin{array}{l}\text { Combined analysis of parts I and } 2 \text { : } \\
\text { Increased sICH at } 36 \text { hours in tPA } \\
\text { group (tPA } 6.4 \% \text { versus placebo } \\
0.6 \% ; P<0.00 \text { I) } \\
\text { No change in overall mortality at }\end{array}$ \\
\hline $\begin{array}{l}\text { NINDS tPA study - } \\
\text { Part } 2(1995)^{\prime}\end{array}$ & tPA $0.9 \mathrm{mg} / \mathrm{kg}$ & 3 hours $(1.5)$ & $\begin{array}{l}\text { Greater favorable outcome in tPA } \\
\text { group on global test statistic at } \\
90 \text { days }^{\ddagger} \\
\text { OR I.7 (Cl I.2-2.6; } P=0.008)\end{array}$ & $\begin{array}{l}90 \text { days (tPA } 17 \% \text { versus placebo } 21 \% \\
P=0.30 \text { ) }\end{array}$ \\
\hline ECASS I $(1995)^{20}$ & tPA $1.1 \mathrm{mg} / \mathrm{kg}$ & 6 hours $(4.3)$ & $\begin{array}{l}\text { No difference in } B I(P=0.99) \text { and } m R S \\
(P=0.4 I) \text { at } 90 \text { days }\end{array}$ & $\begin{array}{l}\text { Increase in large parenchymal ICH } \\
\text { (tPA } 20 \% \text { versus placebo } 7 \% ;(P<0.00 \text { I } \\
\text { No difference in } 30 \text {-day mortality (tPA } \\
18 \% \text { versus placebo } 13 \% ; P=0.08)\end{array}$ \\
\hline ECASS II $(1998)^{29}$ & tPA $0.9 \mathrm{mg} / \mathrm{kg}$ & $\begin{array}{l}6 \text { hours (NR }-80 \% \\
\text { between } 3 \text { and } \\
6 \text { hours) }\end{array}$ & $\begin{array}{l}\text { No difference in favorable outcome } \\
\text { (mRS) at } 90 \text { days (tPA } 40.3 \% \text { versus } \\
\text { placebo } 36.3 \% \text {; OR I.2 [Cl } 0.9-1.6] \text {; } \\
P=0.28 \text { ) }\end{array}$ & $\begin{array}{l}\text { Increased } \mathrm{sICH} \text { up to } 7 \text { days (tPA } \\
8.8 \% \text { versus placebo } 3.4 \% \text { ) }\end{array}$ \\
\hline $\begin{array}{l}\text { ATLANTIS-A } \\
(2000)^{19}\end{array}$ & tPA $0.9 \mathrm{mg} / \mathrm{kg}$ & 6 hours $(4.6)$ & $\begin{array}{l}\text { Increased early clinical improvement in } \\
\text { tPA group ( }>4 \text { increase in NIHSS) } \\
\text { (tPA } 40 \% \text { versus placebo } 21 \% ; P=0.02 \text { ) } \\
\text { Decreased clinical improvement at } \\
30 \text { days for tPA group (tPA } 60 \% \\
\text { versus placebo } 75 \% ; P=0.05 \text { ) }\end{array}$ & $\begin{array}{l}\text { Increased sICH up to IO days (tPA } \\
I I \% \text { versus placebo } 0 \% ; P<0.0 I \text { ) } \\
\text { Increase mortality at } 90 \text { days (tPA } \\
23 \% \text { versus placebo } 7 \% ; P<0.0 I \text { ) }\end{array}$ \\
\hline $\begin{array}{l}\text { ATLANTIS-B } \\
(1999)^{49}\end{array}$ & tPA $0.9 \mathrm{mg} / \mathrm{kg}$ & $3-5$ hours $(4.6)$ & $\begin{array}{l}\text { No difference in excellent neurologic } \\
\text { recovery (NIHSS } \leq 1 \text { ) (tPA } 34.5 \% \\
\text { versus placebo } 34 \% ; P=0.89 \text { ) }\end{array}$ & $\begin{array}{l}\text { Increased sICH up to } 10 \text { days (tPA } \\
7 \% \text { versus placebo } I .1 \% ; P<0.00 I \text { ) } \\
\text { No difference in mortality (tPA } \\
I I \% \text { versus placebo } 6.9 \% ; P=0.09 \text { ) }\end{array}$ \\
\hline ECASS III (2009) $)^{33}$ & tPA $0.9 \mathrm{mg} / \mathrm{kg}$ & $3.0-4.5$ hours $(4.0)$ & $\begin{array}{l}\text { Greater favorable outcome }(\mathrm{mRS}) \text { in } \\
\text { tPA group at } 90 \text { days (OR I.34 } \\
[\text { CI I.0-I.8; } P=0.04])\end{array}$ & $\begin{array}{l}\text { Increased sICH (tPA } 2.4 \% \text { versus } \\
\text { placebo } 0.2 \% ; P=0.008 \text { ) } \\
\text { No difference in mortality (tPA } \\
7.7 \% \text { versus placebo } 8.4 \% ; P=0.68 \text { ) }\end{array}$ \\
\hline
\end{tabular}

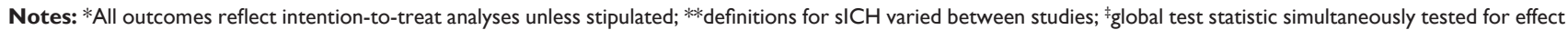
in all four outcome measures: BI, mRS, Glasgow outcome scale, and NIHSS.

Abbreviations: ATLANTIS, Alteplase Thrombolysis for Acute Noninterventional Therapy in Ischemic Stroke; Bl, Barthel index; Cl, confidence interval; ECASS, European Cooperative Acute Stroke Study; mRS, modified Rankin Scale; NIHSS, National Institutes of Health Stroke Scale score; NINDS, National Institute of Neurological Disorders and Stroke; NR, not reported; OR, odds ratio; sICH, symptomatic intracerebral hemorrhage; tPA, tissue plasminogen activator; RR, relative risk; ICH, intracerebral hemorrhage. 
during the first 36 hours (tPA 6\% versus placebo $0.6 \%$ ); nevertheless, there was no statistically significant difference in overall mortality between the groups (tPA $17 \%$ versus placebo $21 \% ; P=0.30){ }^{1}$

A principal criticism of the results focused on the lack of significant improvement in neurological deficits at 24 hours by the outcome of 4 or more point reduction in the National Institutes of Health (NIH) Stroke Scale (NIHSS) (0-42, $0=$ no deficits). ${ }^{21}$ However, post hoc analyses revealed that there was a significant neurological improvement at 24 hours if the defined outcome had been a 5 or more point reduction on the NIHSS. That is to say, the efficacy of tPA would have been appreciated with more substantial improvement between the treatment and placebo arms at 24 hours, but the study did not adequately estimate the natural history of recovery at 3 months. ${ }^{22,23}$

Other large randomized trials were published during that time period yielding conflicting results that revealed no benefit of IV thrombolysis in acute stroke care and increase in risk of hemorrhage. ${ }^{20}$ Study design and criteria utilized by these studies were different from the NINDS tPA study, such as: use of different thrombolytic agents (eg, streptokinase), time period for treatment (eg, up to 6 hours), and use of increased doses of tPA and/or concomitant antithrombotics. ${ }^{20,24,25}$ Based on the results of the NINDS study, the ATLANTIS-B and ECASS (European Cooperative Acute Stroke Study) II studies were designed to evaluate the safety and efficacy of tPA within 3-5 hours and up to 6 hours from stroke onset, respectively; both failed to demonstrate primary efficacy. ${ }^{20,26}$ However, when the same global endpoint analysis used in the NINDS trial was applied to the ECASS I data, a favorable outcome in the tPA-treated group was observed. ${ }^{27}$ Figure $1 \mathrm{~A}$ and $\mathrm{B}$ demonstrate point estimates for odds ratios (ORs) and 95\% confidence intervals (CIs) between the tPA and control groups for each of the trials

A Efficacy results of major tPA clinical trials: death or dependency defined as $\mathrm{mRS} 2$ to 6

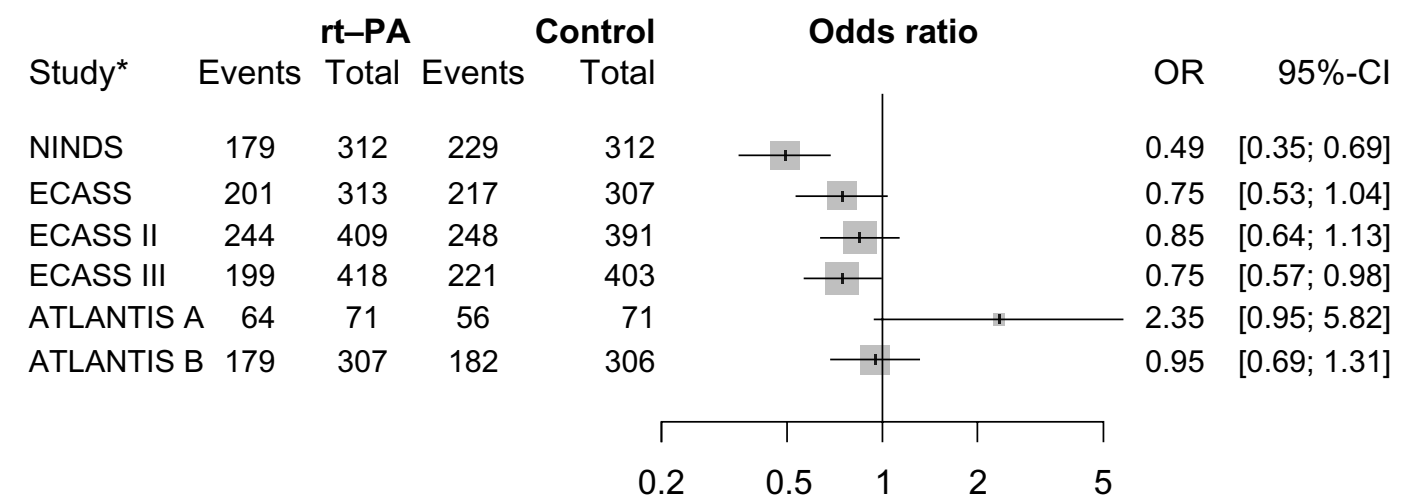

Favors thrombolysis Favors control

\section{B Safety results of major tPA clinical trials: symptomatic intracerebral hemorrhage within 7 to 10 days}

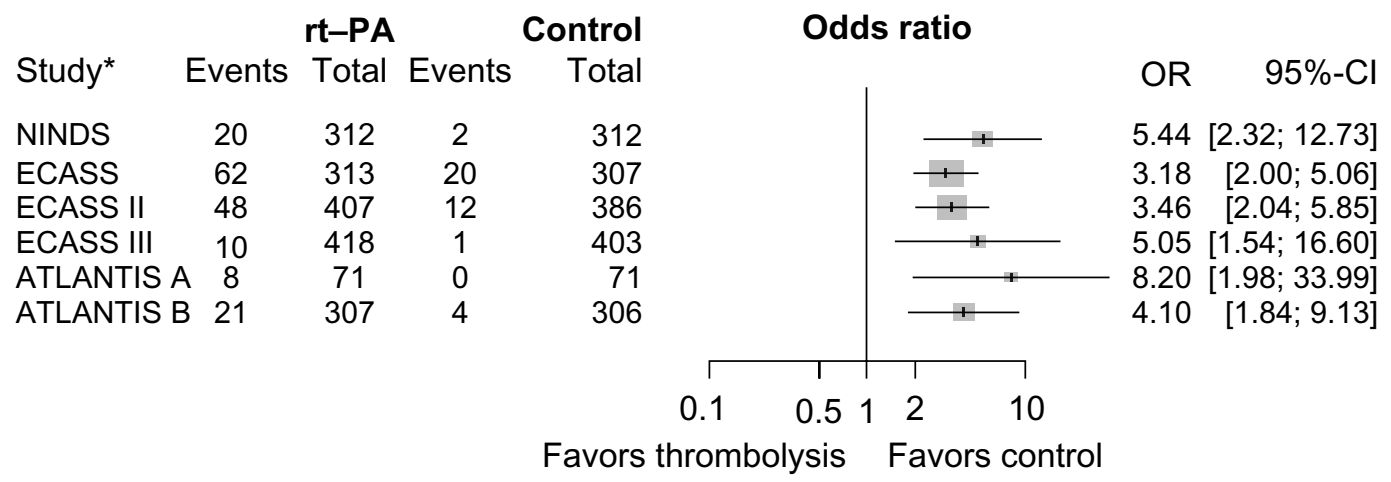

Figure I (A) Death or dependency defined as mRS 2-6. (B) Risk of symptomatic intracerebral hemorrhage.

Notes: A and B demonstrate point estimates for ORs and $95 \% \mathrm{Cls}$ between the tPA and control groups for each of the trials. *References for the listed trials: NINDS, ${ }^{*}$ ECASS, ${ }^{20}$ ECASS $11,{ }^{29}$ ATLANTIS-A, ${ }^{19,28}$ ATLANTIS-B, ${ }^{49}$ and ECASS $111 .{ }^{33}$

Abbreviations: ATLANTIS, Alteplase Thrombolysis for Acute Noninterventional Therapy in Ischemic Stroke; Cl, confidence interval; ECASS, European Cooperative Acute Stroke Study; mRS, modified Rankin Scale; NINDS, National Institute of Neurological Disorders and Stroke; OR, odds ratio; rt-PA, recombinant tissue plasminogen activator; tPA, tissue plasminogen activator. 
listed in Table 1. With the exception of ATLANTIS-A, which had the fewest numbers and least precision, ORs ranged from 0.49 to 0.95 for death or dependency, defined as modified Rankin scale (mRS) 2-6 favoring tPA (Figure 1A). For sICH within 7-10 days, ORs ranged from 3.18 to 8.20, favoring control (Figure 1B). ${ }^{1,19,20,28,29,33,49}$ These findings are supported by Wardlaw et al, ${ }^{28}$ who reviewed all randomized trials of any thrombolytic agent versus control conducted from 1966 to 2008. The early clinical trials of IV tPA in AIS supported its efficacy and ultimate FDA-approval for patients presenting within 0-3 hours from onset; an additional common result of these early studies revealed an increased risk of sICH without affecting overall mortality. ${ }^{19,20,26,28,29}$ In addition, it became evident that two main factors play a vital role in the overall efficacy and risk of hemorrhage: time-to-treatment and adherence to treatment protocol.

\section{The importance of time- to-treatment}

From the practice-changing results of the NINDS study, the precise therapeutic window for tPA in AIS was still debated. Ongoing clinical trials continued to test extended thrombolysis times. $^{30,31}$ While both ECASS II and ATLANTIS-B failed to show benefit from 3 to 6 hours, with an increased risk of sICH, it was unclear whether there was any benefit within 3-4 hours given low statistical power. ${ }^{20,21,26,29}$ A pooled analysis of the ATLANTIS, ECASS, and NINDS tPA studies in 2004 suggested a favorable outcome up to 4.5 hours, with an OR of 1.40 (CI 1.05-1.85). ${ }^{32}$ The results of the pooled analysis prompted the ECASS III study, which was designed to evaluate the efficacy and safety of tPA in AIS between 3 and 4.5 hours. The study applied additional exclusion criteria to comply with the European Medicines Evaluation Agency, including history of diabetes and a prior stroke, age $>80$ years, and NIHSS $>25$. The primary results demonstrated a favorable outcome for patients treated with tPA compared with placebo within 4.5 hours of symptom onset (tPA $52.4 \%$ versus placebo 45.2\%; OR 1.34 [CI 1.02-1.76]; $P=0.04$ ). ${ }^{33}$ Notable differences in ECASS III compared with the NINDS study were a lower enrollment stroke severity in both groups, a higher percentage of the placebo arm with a history of prior stroke, and the additional exclusions limiting generalizability for older patients with more severe strokes. Nonetheless, the AHA/ASA updated guidelines to support the use of tPA in this extended time window for carefully selected patients. ${ }^{34}$ To date, the use of tPA beyond 3 hours from stroke onset has not been approved for extended labeling by the FDA and remains an off-label indication in the United States.
Early laboratory and clinical pilot studies have alluded to the concept of time-to-treatment as a predictor for a good

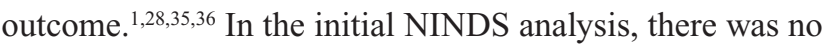
significant observed difference between the stratification of 0-90 minutes versus 91-180 minutes. ${ }^{1,37}$ However, further analysis suggested increased odds for early clinical improvement and favorable outcome at 3 months in patients stratified to 0-90 minutes. The pooled analyses by Marler et $\mathrm{al}^{38}$ and Hacke et $\mathrm{al}^{32}$ further demonstrated a direct relationship between time and treatment effect. Saver et al ${ }^{39}$ in 2006 further elucidated, "time is brain" quantitatively in humans by utilizing magnetic resonance imaging (MRI)based infarct volumetrics. The author identified that with every passing minute until reperfusion is achieved, about 2 million neurons and 14 billion synapses are lost. ${ }^{39}$ Most recently, a study of 58,353 tPA-treated patients highlighted that for every 15-minute improvement in time-to-treatment, patients were less likely to die (OR 0.96 [CI 0.95-0.98]; $P<0.001$ ), experience sICH (OR 0.96 [CI 0.95-0.98]; $P<0.001$ ), and were more likely to be ambulatory at discharge (OR 1.04 [CI 1.03-1.05]; $P<0.001) .{ }^{40}$ This study underscores the importance of innovative models of prehospital care to improve the rapidity of treatment. ${ }^{41-43}$

Based on the most current 2013 AHA/ASA guideline update regarding fibrinolysis in acute stroke, tPA is recommended for eligible patients who present within 3 hours of stroke onset and up to 4.5 hours in eligible patients, with the following additional exclusions: patients $>80$ years of age, those taking oral anticoagulants regardless of international normalized ratio (INR), baseline NIHSS $>25$, those with imaging evidence of ischemic injury involving more than one third of the middle cerebral artery territory, and those with a history of both stroke and diabetes mellitus..$^{28,34}$

\section{Side effects of IV tPA and risk of hemorrhagic outcomes}

Although intracerebral hemorrhage (ICH) is the most feared complication of tPA, other potential adverse reactions including anaphylaxis/angioedema, systemic bleeding, and myocardial rupture occur less commonly. Myocardial rupture has been associated with patients receiving IV tPA within days of an acute myocardial infarction (MI) ${ }^{34}$ While comorbid acute MI is listed as a relative contraindication to IV tPA, treatment in this setting must be assessed on a case-by-case basis regarding stroke severity and overall risk to benefit; particularly considering that fibrinolytic therapy is actually in the treatment pathway for acute STEMI (ST segment elevation MI) when percutaneous coronary intervention is delayed. ${ }^{44}$ 
Signs of pericarditis are a more concerning contraindication for use of systemic tPA given the possibility of pericardial hemorrhage and tamponade.

Orolingual angioedema occurs in roughly $1 \%-5 \%$ of AIS patients treated with IV tPA. The reaction is typically contralateral to the location of the stroke and associated with infarcts involving the frontal and insular cortices. The concomitant use of angiotensin-converting enzyme inhibitors increases the risk due to excess bradykinin, and the reaction, although typically transient, can be treated with antihistamines or steroids. ${ }^{34,45}$

As stated above, the most important concern associated with the use of tPA in acute stroke patients is the fear of hemorrhagic complications. A number of factors pertain to risk of poor outcome from hemorrhage, such as location, nature of hemorrhage (hemorrhagic infarcts versus parenchymal hematomas), clinical status (symptomatic versus asymptomatic), and temporal relationship to treatment. ${ }^{46-48}$ In the NINDS study, the disease-related mortality rate in sICH cases was $47 \%$, but the global mortality rate in all tPA-treated patients was lower compared with placebo. Other subsequent trials, except for ATLANTIS-A, revealed a similar increase in sICH for tPA-treated patients, with no difference in overall mortality. ${ }^{1,19,20,26,29,49}$ Analysis of ECASS II revealed an association of parenchymal hematomas and sICH with tPA but not hemorrhagic infarcts. ${ }^{50}$
Additional studies and meta-analysis have reported differing rates of hemorrhage, ${ }^{32,48,51,52}$ in part due to varying definitions of $\mathrm{sICH}$, including differences in measures of neurological symptoms, temporal relationship to treatment, and radiographic characteristics (Table 2) ${ }^{53,54}$ For instance, the sICH rate in ECASS III was 5\% lower than in the NINDS study. However, when the NINDS definition is applied, the rate is higher than in the NINDS study (7.9\%). ${ }^{33}$

\section{Hemorrhagic risk and prognostic factors}

Over the years, several pretreatment risk factor profiles have been studied to discern which individuals are more likely to benefit from tPA or to be at risk of sICH. ${ }^{55-59}$ In 1997, a post hoc subgroup analysis of the NINDS tPA data identified age-by-deficit severity interaction, history of diabetes, age-by-blood pressure interaction, and early computed tomography (CT) findings as factors altering long-term outcome in both groups, but no interaction was found with efficacy of tPA; therefore, tPA-treated patients in both groups still benefited. In addition, the only variables associated with increased risk of sICH were stroke severity, presence of brain edema, and mass effect on CT prior to treatment. ${ }^{60}$ Since then, a number of analyses have reported additional baseline factors associated with tPA-related functional outcomes and risk of hemorrhagic transformation (Table 3). ${ }^{50,52,56,57}$

Table 2 tPA-related hemorrhage as defined by different stroke studies

\begin{tabular}{|c|c|c|c|}
\hline Study name & Hemorrhage type & Radiographic and clinical definition & Rate of hemorrhage \\
\hline NINDS $^{\prime, 48}$ & $\mathrm{HI}$ and $\mathrm{PH}$ & $\begin{array}{l}\text { - HI: punctate hyperdensities with indistinct borders } \\
\text { in infarct bed with no mass effect. } \\
\text { - PH: homogenous hematoma in infarct bed, with } \\
\text { sharply defined borders and associated mass effect. } \\
\text { - Any neurological deterioration within } 36 \text { hours of tPA. }\end{array}$ & $\begin{array}{l}\text { Symptomatic intracranial } \\
\text { hemorrhage: } 6.4 \% \text {. } \\
\text { Asymptomatic intracranial } \\
\text { hemorrhage: } 30 \% .\end{array}$ \\
\hline \multirow[t]{2}{*}{ ECASS I and II20,29 } & $\mathrm{HI} \mathrm{I}$ and 2 & $\begin{array}{l}\text { - HI I: small punctate hemorrhage (along margins of infarct) } \\
\text { in stroke bed, no mass effect. } \\
\text { - HI 2: confluent petechiae (within infarcted tissue) in } \\
\text { stroke bed, no mass effect. } \\
\text { - }>4 \text { point increase in baseline NIHSS within } 7 \text { days. }\end{array}$ & ECASS II HI I 19.6\%, HI 2 15.2\%. \\
\hline & $\mathrm{PH} \mathrm{I}$ and 2 & $\begin{array}{l}\text { - PH I: hematoma occupying } \leq 30 \% \text { of infarcted area } \\
\text { with mild mass effect. } \\
\text { PH 2: hematoma occupying }>30 \% \text { of infarcted area } \\
\text { with significant mass effect. } \\
\text { - }>4 \text { point increase in baseline NIHSS within } 7 \text { days. }\end{array}$ & ECASS II: PH I 3.7\%, PH 2 8. I\%. \\
\hline SITS-MOST T3,52 & $\mathrm{PH}$ & $\begin{array}{l}\text { - Local or remote } \mathrm{PH} \text { with associated decline in NIHSS. } \\
\text { - ICH type PH } 2 \text {. } \\
\text { - } \geq 4 \text { point increase in baseline NIHSS within } 24 \text { hours. }\end{array}$ & $\begin{array}{l}\text { Symptomatic intracranial } \\
\text { hemorrhage } 1.7 \% \text { at } 24 \text { hours. }\end{array}$ \\
\hline ECASS $I I I^{33}$ & $\mathrm{PH}$ & $\begin{array}{l}\text { Apparent intra or extraparenchymal blood associated } \\
\text { with } \geq 4 \text { point increase in baseline NIHSS that led to } \\
\text { death or neurological deterioration. }\end{array}$ & $\begin{array}{l}\text { Symptomatic intracranial } \\
\text { hemorrhage } 2.4 \% \text {. }\end{array}$ \\
\hline
\end{tabular}

Abbreviations: ECASS, European Cooperative Acute Stroke Study; HI, hemorrhagic infarct; PH, parenchymal hematoma; NIHSS, National Institutes of Health Stroke Scale; NINDS, National Institute of Neurological Disorders and Stroke; SITS-MOST, Safe Implementation of Thrombolysis in Stroke-Monitoring Study; tPA, tissue plasminogen activator; $\mathrm{ICH}$, intracerebral hemorrhage. 
Table 3 Risk factor profiles associated with negative outcomes after use of tPA in acute ischemic stroke

\begin{tabular}{lllll}
\hline & ICH & & Poor functional outcomes $^{52,57}$ & Mortality $^{52,58}$ \\
\hline Risks factors & Diabetes & Systolic BP & Age & Pre-stroke mRS \\
& CHF & Early CT changes & Stroke severity & Diastolic BP \\
& Atrial fibrillation & Serum glucose & Diabetes & Antiplatelet use other than aspirin \\
Stroke severity & Platelet count & Blood pressure & CHF \\
& Age & Weight & Early CT findings & Centers' previous stroke \\
& Time-to-treatment & Tobacco use & Male & experience \\
& Antiplatelet use & & & Male \\
& & & Age \\
& & & Atrial fibrillation \\
\hline
\end{tabular}

Abbreviations: BP, blood pressure; $\mathrm{CHF}$, congestive heart failure; $\mathrm{CT}$, computed tomography; mRS, modified Rankin Scale; tPA, tissue plasminogen activator; ICH, intracerebral hemorrhage.

Moreover, the occurrence of sICH has been correlated with worsened 3-month outcomes. ${ }^{53,54,57}$ Using NINDS trial data, Saver ${ }^{61}$ calculated a number-needed-to-harm of 126 tPA-treated patients for every one case of sICH leading to severe disability or death, and a number-needed-to-treat of 17 to cause one protocol-defined sICH. A similar analysis of the 3.0-4.5-hour window using ECASS III data revealed an number-needed-to-harm of $35 .^{62}$ These figures are countered, however, by a number-needed-to-benefit of 7-8 in both trials favoring treatment.

\section{Risk and prognostic stratification scales}

A number of statistical prognostic models have derived scores attempting to stratify treatment by predicted risk and outcomes (Table 4). However, such decision-support tools raise ethical questions regarding whether tPA can be withheld in an otherwise eligible patient based on a risk/ prognostic stratification score. Additionally, further external validation in independent cohorts is required prior to utilization in clinical practice. ${ }^{63}$ Ongoing research of advanced multimodal imaging and other biomarkers may someday potentiate the utility of decision-support tools for acute stroke treatment.

\section{Imaging-guided thrombolysis}

Rapid acquisition of a non-contrasted CT scan of the head is universally part of acute stroke treatment protocol, primarily to rule out ICH as exclusion for tPA treatment, although other exclusions such as early infarction in more than two-thirds of a vascular territory have been suggested. ${ }^{34,64}$ With technological advancements in multimodal CT and MRI, imaging-guided thrombolysis has gained interest as a potential tool to identify the extent of salvageable tissue, otherwise known as the ischemic penumbra. Davalos et al $^{64}$ initially proposed a clinical-radiological mismatch in 2004 as a means of estimating treatment outcome. The
DEFUSE (Diffusion and Perfusion Imaging Evaluation for Understanding Stroke Evolution), EPITHET (Echoplanar Imaging Thrombolytic Evaluation Trial), and MR RESCUE (Magnetic Resonance and Recanalization of Stroke Clots Using Embolectomy) studies all proposed varying definitions of imaging-based penumbral assessment, but none of these trials has demonstrated that the use of such imaging can identify a population that has improved outcomes with intervention than those without it. ${ }^{65-67}$ For now, the utility of perfusion-based imaging to guide tPA treatment decisions remains to be proven.

\section{The benefits and risks of IV thrombolysis in certain subgroups}

Based on both the clinical trial and subsequent clinical practice experience, a number of subgroups of stroke patients have been identified in whom effectiveness and safety of tPA varies. Here, we highlight a few of the more commonly encountered subgroups for which treatment decisions remain challenging in clinical practice.

\section{Mild and rapidly improving}

Studies evaluating exclusion criteria for receiving tPA highlight that $29 \%-43 \%$ of patients are excluded from thrombolysis for rapidly improving or mild symptoms (RIMS). ${ }^{68-71}$ The assumption has been made that mild and/or rapidly improving strokes will follow a natural course of favorable functional outcome in spite of accepting the additional risk of tPA. However, a few small studies have demonstrated that about a third of these patients left untreated will die or are unable to be discharged home due to neurological dysfunction. ${ }^{72,73}$ Rajajee et al $^{73}$ identified a large-vessel occlusion on magnetic resonance angiography corresponding to the acute stroke in $33 \%$ of patients excluded from tPA due to RIMS. The findings were later supported using results from a large nationwide database, with $28.3 \%$ of untreated patients with RIMS not discharged home and $28.5 \%$ unable to ambulate 
Table 4 Risk and prognostic stratification scales

\begin{tabular}{|c|c|c|}
\hline Risk score & Variables & Assessment \\
\hline Cucchiara et al ${ }^{115}$ & $\begin{array}{l}\text { Age, NIHSS, admission } \\
\text { glucose, and platelet count } \\
\text { on admission }\end{array}$ & $\mathrm{ICH}$ \\
\hline $\mathrm{HAT}^{116}$ & $\begin{array}{l}\text { Admission glucose on, } \\
\text { NIHSS, hypodensity of CT } \\
\text { scan, and DM }\end{array}$ & $\mathrm{ICH}$ \\
\hline SITS-SICH ${ }^{59}$ & $\begin{array}{l}\text { Age, NIHSS, glucose on } \\
\text { admission, SBP, bodyweight, } \\
\text { OTT, ASA monotherapy, } \\
\text { ASA + clopidogrel, and } \\
\text { history of HTN }\end{array}$ & $\mathrm{ICH}$ \\
\hline GRASPS ${ }^{17}$ & $\begin{array}{l}\text { Age, NIHSS, admission } \\
\text { glucose, SBP, ethnicity, } \\
\text { and sex }\end{array}$ & $\mathrm{ICH}$ \\
\hline SEDAN $^{118}$ & $\begin{array}{l}\text { Age, NIHSS, HDMCA sign } \\
\text { on CT, early infarct signs on } \\
C T \text {, and admission glucose }\end{array}$ & $\mathrm{ICH}$ \\
\hline DRAGON"19 & $\begin{array}{l}\text { HDMCA or early infarct } \\
\text { signs on CT, prestroke } \\
\text { mRS score, age, admission } \\
\text { glucose, OTT, and NIHSS }\end{array}$ & $\begin{array}{l}\text { Functional } \\
\text { outcome }\end{array}$ \\
\hline SPAN- 100 index $x^{120}$ & Age and NIHSS & $\begin{array}{l}\text { Functional } \\
\text { outcome }\end{array}$ \\
\hline iSCORE $^{121}$ & $\begin{array}{l}\text { Age, sex, CNS, stroke } \\
\text { subtype, AF, CHF, cancer, } \\
\text { renal failure on dialysis, } \\
\text { preadmission disability, } \\
\text { and admission glucose }\end{array}$ & $\begin{array}{l}\text { Functional } \\
\text { outcome }\end{array}$ \\
\hline Stroke-TPI ${ }^{122}$ & $\begin{array}{l}\text { NIHSS score, history of } \\
\text { stroke, SBP, OTT, age, sex, } \\
\text { and DM }\end{array}$ & $\begin{array}{l}\text { Functional } \\
\text { outcome }\end{array}$ \\
\hline ASTRAL $^{123}$ & $\begin{array}{l}\text { Age, NIHSS, time-of-onset } \\
\text { to admission, LOC, range of } \\
\text { visual fields, and admission } \\
\text { glucose }\end{array}$ & $\begin{array}{l}\text { Functional } \\
\text { outcome }\end{array}$ \\
\hline
\end{tabular}

Abbreviations: AF, atrial fibrillation; ASA, aspirin; ASTRAL, Acute Stroke Registry and Analysis of Lausanne; CHF, congestive heart failure; CNS, Canadian neurological Scale; CT, computed tomography; DM, diabetes mellitus; GRASPS, Guidance on Risk Assessment and Stroke Prevention Score; HAT, hemorrhage after thrombolysis; HDMCA, hyperdense middle cerebral artery; HTN, hypertension; iSCORE, ischemic stroke predictive risk score; LOC, level of consciousness; mRS, modified Rankin Scale; NIHSS, National Institutes of Health Stroke Scale score; OTT, onset-to-treatment time; SBP, systolic blood pressure; SITS-SICH, Safe Implementation of Treatments in Stroke - Symptomatic Intracerebral Hemorrhage; SPAN, Stroke Prognostication using Age and NIH Stroke Scale; TPI, thrombolytic predictive instrument; ICH, intracerebral hemorrhage; SEDAN, Sugar, Early infarct signs, (hyper)Dense cerebral artery sign on admission CT scan, Age, and NIHSS on admission; DRAGON, (hyper)Dense cerebal artery sign/early infarct signs on admission CT scan, prestroke modified Rankin scale, Age, Glucose level at baseline, Onset-to-treatment time and baseline NIHSS

without assistance at discharge. ${ }^{72}$ Whereas all of the above studies evaluated outcomes at time of discharge, Nedeltchev et $\mathrm{al}^{74}$ evaluated 3-month outcomes for untreated patients with RIMS and found that $75 \%$ had a favorable outcome. However, three small studies have shown a significant improvement in clinical outcome with no increased risk of hemorrhage in tPA-treated RIMS patients. ${ }^{75-77}$ These were supported by a subgroup analysis from the ECASS III study, revealing similar efficacy of tPA in both mild and more severe strokes. ${ }^{78}$ A prospective, randomized placebo-controlled trial has been proposed to evaluate stroke patients with non-disabling deficits within 4.5 hours of onset. ${ }^{79,80}$

\section{Older age}

A third of the patients presenting with ischemic stroke are over the age of $80 .^{81,82}$ Kammersgaard et $a^{83}$ evaluated the short- and long-term prognosis in elderly stroke patients and revealed that patients over 80 were more likely to die in the hospital and less likely to have a favorable outcome. In addition, elderly patients may be at an increased risk of ICH due to cerebral amyloid angiopathy, impaired renal clearance, and frail vasculature. ${ }^{84-86}$ Many clinicians withhold treatment due to fear that age is associated with poor prognosis and increased risk of hemorrhage. With the exception of the NINDS study, patients $\geq 80$ were excluded from the early clinical tPA trials. Of the 49 patients over the age of 75 included in the NINDS tPA trial, outcome was related to age-by-neurologic deficit but did not alter treatment effect. In addition, age did not independently increase the risk of hemorrhage. ${ }^{60}$ Tanne et a ${ }^{87}$ found comparable favorable outcomes and risks in patients aged $\geq 80$ versus $<80$. Conversely, several studies that followed reported a reduction in favorable outcome and increased mortality in tPA-treated patients aged $\geq 80$ compared with their younger counterparts, with conflicting sICH rates ${ }^{88-92}$ Notable limitations of the above studies were small sample size, retrospective analysis, and confounding factors (eg, preexisting disability and comorbidities). In 2010, Mishra et $\mathrm{a}^{93}$ compared elderly patients treated with thrombolysis with those not treated, from two large registries. They reported favorable outcomes independently among patients aged $\leq 80($ OR 1.6 [CI 1.5-1.7]; $P<0.001)$ and in those $>80$ (OR 1.4 [CI 1.3-1.6]; $P<0.001$ ). In addition, there was a slight increase of sICH among patients $>80$ but not statistically significant $(P=0.07) \cdot{ }^{93}$ Despite the increased power, the treatment allocation was not randomized, and therefore the results are subject to bias and confounding. The Third International Stroke Trial (IST-3) was the first prospective randomized trial to include a sizable number of patients $>80$ years (53\%). A subgroup analysis from IST-3 suggested a greater benefit from $\mathrm{PA}$ in patients older than 80 compared with their younger counterparts $(P=0.027) .{ }^{94}$ Based on these results, tPA should not be withheld based purely on age, and in fact, patients older than 80 may do as well if not better with treatment compared with control. As worldwide life expectancy and incidence of stroke in the elderly continue to increase 
Table 5 Common stroke mimics

Seizure
Migraine
Conversion disorder
Demyelinating disease
Encephalitis/meningitis
Toxic/metabolic encephalopathy (hypoglycemia, electrolyte disarray, etc)
Multiple sclerosis
Brain tumor/mass
Stroke reactivation (anamnestic syndrome)

in the future, the importance of treating older stroke patients will continue to hold relevance. ${ }^{95}$

\section{Stroke mimics}

Complicating treatment decisions, numerous disease processes mimic stroke symptoms. Table 5 lists some of the more common masqueraders of stroke with conversion disorder, complicated migraine, and seizures being the most frequently encountered. ${ }^{96-100}$ The need for rapid recognition and treatment of AIS potentiates the likelihood of administering tPA to a stroke mimic. The fraction of stroke mimics among tPA-treated patients in various cohorts has been reported between $1 \%$ and $31 \%$, with community hospitals reporting rates as high as $25 \%-29 \%{ }^{97,100-106}$ Some variation in these percentages reflect the lack of standard mimic definitions and/or inaccuracies in diagnosis reporting. ${ }^{101}$ There have been a number of studies evaluating the characteristics, risk, and functional outcome of tPA-treated stroke mimics. Common characteristics of stroke mimics are young age, female sex, no or few baseline risk factors, left hemispheric syndromes, and milder presenting stroke severity. ${ }^{97,100,106,107}$ In addition, aphasia, particularly when global and not presenting with any other deficits, is one of the most commonly cited presentations of stroke mimics. ${ }^{106,107}$ The safety of tPA in stroke mimics was evaluated in a multicenter observational study that revealed an $\mathrm{sICH}$ rate of $1.0 \%$ (CI $0.0-5.0$ ) in mimics compared with $7.9 \%$ (CI 7.2-8.7) in imaging-confirmed ischemic stroke. Predictably, treated stroke mimics were more likely to experience an excellent outcome at 3 months compared with AIS (75\% versus $39.5 \% ; P<0.0001) .{ }^{107}$ Further studies have supported the safety of tPA use in stroke mimics, with minimal complicating disability or ICH. ${ }^{98-100,102}$

\section{Translating trials to clinical practice experience}

Both academic and community-based studies have sought to evaluate whether tPA is as effective and safe when integrated into clinical practice as demonstrated in the controlled setting of clinical trials. Indeed, community-based studies and large clinical databases have elicited similar and, in some cases, lower rates of sICH than those revealed in trials (Table 6). In populations where sICH rates were higher, adherence to strict guidelines and protocols likely varied. ${ }^{108}$ Hill and Buchan ${ }^{109}$ reported an association between sICH and frequency of protocol violations, but no correlation with worse functional outcomes. Not surprisingly, a survey of practice patterns has found that tPA experience and neurological expertise are associated with fewer protocol violations in general. ${ }^{110}$ Overall, results from clinical trials of IV tPA in stroke have been widely generalizable to the clinical practice experience.

Table 6 Community-based studies on the experience of tPA utilization for acute ischemic stroke

\begin{tabular}{|c|c|c|c|c|c|}
\hline Study (year) & Type & $\begin{array}{l}\text { Number of } \\
\text { hospitals }\end{array}$ & $\begin{array}{l}\text { Number of patients } \\
\text { (percentage treated } \\
\text { with tPA) }\end{array}$ & $\begin{array}{l}\text { sICH } \\
\text { (24-36 hours) }\end{array}$ & $\begin{array}{l}\text { Protocol } \\
\text { violations* }\end{array}$ \\
\hline Houston $(1998)^{124}$ & Prospective & 3 & $30(2.9 \%)$ & $7.0 \%$ & $10.0 \%$ \\
\hline Cologne, Germany (1998) ${ }^{125}$ & Prospective & I & $100(22.0 \%)$ & $5.0 \%$ & $3.0 \%$ \\
\hline Cleveland $(2000)^{126}$ & Prospective & 29 & $70(1.8 \%)$ & $15.7 \%$ & $50.0 \%$ \\
\hline OSF Stroke Network (2000) & Prospective & 14 & 57 (6.3\%) & $5.3 \%$ & $8.7 \%$ \\
\hline STARS study $(2000)^{128}$ & Prospective & 57 (US) & 389 (NR) & $3.3 \%$ & $32.6 \%$ \\
\hline Indianapolis $(200 I)^{129}$ & Retrospective & 10 & $50(N R)$ & $8.0 \%$ & $16.0 \%$ \\
\hline Houston $(2001)^{130}$ & Prospective & 4 & $269(15.0 \%)$ & $4.5 \%$ & $13.0 \%$ \\
\hline Berlin, Germany $(200 I)^{131}$ & Prospective & 1 & 75 (9.4\%) & $2.7 \%$ & $20.0 \%$ \\
\hline Connecticut $(2002)^{132}$ & Retrospective & 16 & $63(0.6 \%)$ & $6.0 \%$ & $97.0 \%$ \\
\hline Cleveland update $(2003)^{133}$ & Retrospective & 9 & $47(2.7 \%)$ & $6.4 \%$ & $19.1 \%$ \\
\hline CASES study $(2005)^{109}$ & Prospective & 60 & $\mathrm{I}, 135(\mathrm{I} .4 \%)$ & $4.6 \%$ & $13.6 \%$ \\
\hline SITS-MOST $(2008)^{52}$ & Prospective & 285 & 6,483 (NR) & $1.7 \%$ & NR \\
\hline
\end{tabular}

Note: *Includes minor and major protocol violations.

Abbreviations: CASES, Canadian Activase for Stroke Effectiveness Study; NR, not reported; OSF, Order of St Francis; sICH, symptomatic intracerebral hemorrhage; SITSMOST, Safe Implementation of Thrombolysis in Stroke-Monitoring Study; STARS, Standard Treatment with Alteplase to Reverse Stroke; tPA, tissue plasminogen activator. 
Despite the overwhelming body of evidence supporting the use of IV TPA in all eligible AIS patients, there remains an undercurrent of reservation in the practicing community at large. In 2005, a national survey of emergency medicine physicians found that $40 \%$ were unlikely to use tPA for ischemic stroke under ideal conditions. Of those unlikely to use tPA, $65 \%$ were apprehensive about risk of hemorrhage, while $23 \%$ believed there was a lack of benefit. ${ }^{111}$ More recently, the emergency medicine community has offered support for the use of tPA for AIS as standard care as demonstrated by guidelines. ${ }^{4}$ In 2013, a survey of Canadian neurologists who routinely take acute stroke call demonstrated that concerns are not limited to emergency medical physicians. The majority of respondents (79\%) were less likely to treat at ages older than 80 , those with dementia, or even patients with severe strokes or from nursing homes. However, a significant percentage (70\%) believed a large left middle cerebral artery territory stroke was a fate worse than death, with the overwhelming majority (96\%) believing IV tPA to be an effective stroke treatment. ${ }^{112}$

Apart from individual or group biases, the medical-legal implications of tPA use in clinical practice are difficult to ignore. Over the years, the agreed-upon standard of care in AIS has shifted liability from risk of sICH with tPA to litigation for not offering treatment in otherwise eligible stroke patients. ${ }^{113,114}$ Guideline statements from AHA/ASA, AAN, and ACEP all suggest IV tPA is standard care for treatment of AIS. ${ }^{2-4,34}$

\section{Conclusion}

From the first human trials to today's current practice, effective tPA treatment for AIS continues to rely on appropriate patient screening, rapid diagnosis and decision making, strict adherence to protocol, and one-size-fits-all time windows. Current evidence-based recommendations for the use of IV tPA in AIS can be referenced from the AHA/ASA 2013 update, titled Guidelines for the Early Management of Patients With Acute Ischemic Stroke (see Tables 10-12 for eligibility criteria and general recommendations for appropriate use).$^{34}$ Prognostic and risk stratification scales and advanced multimodal imaging may one day guide treatment decisions, but these tools have not yet been established to guide clinical practice.

Analysis of recent census data suggests that the incidence of AIS will nearly double to 1.5 million per year by $2050 .{ }^{95} \mathrm{In}$ the meantime, stroke remains a leading cause of serious longterm disability and death worldwide, and almost 20 years since its approval, IV tPA remains an underutilized, yet highly efficacious first-line treatment. Ongoing and future research investigating innovative approaches to timelier treatment and novel means of stroke thrombolysis will no doubt continue to revolutionize acute stroke care.

In addition to research focused on acute stroke treatment delivery, there continue to be a number of ongoing trials regarding the risk and efficacy of IV tPA in a number of patient subgroups. Active studies are investigating a variety of potential variables affecting the use of tPA in stroke including but not limited to age, weight, hyperglycemia, dialysis, time-to-presentation, and mild or rapidly improving symptoms. Reference to these and other ongoing studies of IV tPA in stroke can be found at http://www.clinicaltrials.gov. For now, promoting education within both the medical community and general public is a sure path to advance the use of IV IPA in all eligible stroke patients and further alleviate the burden of stroke for our society. After all, in addition to the code of "primum non nocere", we must also consider autonomy and beneficence.

\section{Author contributions}

Sherita N Chapman conceived and designed the manuscript, carried out data acquisition, and critically revised the manuscript. Prachi Mehndiratta designed the manuscript, carried out data acquisition, and critically revised the manuscript. Michelle C Johansen conceived and designed the manuscript, carried out data acquisition, and critically revised the manuscript. Timothy L McMurry carried out statistical analysis and drafted forest plots, and helped design and critically revise the manuscript. Karen C Johnston and Andrew M Southerland conceived, drafted, and critically revised the manuscript.

\section{Disclosure}

Karen C Johnston reports her role as chair of the Data and Safety Monitoring Board for PRISMS trial. The other authors report no conflicts of interest in this work.

\section{References}

1. Tissue plasminogen activator for acute ischemic stroke. The National Institute of Neurological Disorders and Stroke rt-PA Stroke Study Group. N Engl J Med. 1995;333:1581-1587.

2. Adams HP Jr, Brott TG, Furlan AJ, et al. Guidelines for thrombolytic therapy for acute stroke: a supplement to the guidelines for the management of patients with acute ischemic stroke. A statement for healthcare professionals from a special writing group of the stroke council, American Heart Association. Stroke. 1996;27:1711-1718.

3. Practice advisory: thrombolytic therapy for acute ischemic stroke - summary statement. Report of the Quality Standards Subcommittee of the American Academy of Neurology. Neurology. 1996;47:835-839.

4. American College of Emergency Physicians; American Academy of Neurology. Clinical policy: use of intravenous tPA for the management of acute ischemic stroke in the emergency department. Ann Emerg Med. 2013;61:225-243. 
5. Go AS, Mozaffarian D, Roger VL, et al. Heart disease and stroke statistics - 2013 update: a report from the American Heart Association. Circulation. 2013;127:e6-e245.

6. Fonarow GC, Smith EE, Saver JL, et al. Improving door-to-needle times in acute ischemic stroke: the design and rationale for the American Heart Association/American Stroke Association's Target: Stroke initiative. Stroke. 2011;42:2983-2989.

7. Caplan LR, Mohr JP, Kistler JP, Koroshetz W. Should thrombolytic therapy be the first-line treatment for acute ischemic stroke? Thrombolysis - not a panacea for ischemic stroke. $N$ Engl J Med. 1997;337:1309-1310; discussion 1313.

8. Firstenberg MS. Thrombolytic therapy in acute ischemic stroke. $N$ Engl J Med. 1997;336:66; author reply 66-67.

9. Clark WM, Lyden PD, Madden KP, Zivin JA. Thrombolytic therapy in acute ischemic stroke. $N$ Engl J Med. 1997;336:65-66; author reply 66-67.

10. Frankel MR. Thrombolytic therapy in acute ischemic stroke. $N$ Engl J Med. 1997;336:65; author reply 66-67.

11. Kirshner HS. Should thrombolytic therapy be the first-line treatment for acute ischemic stroke? $N$ Engl J Med. 1998;338:761-762; author reply $762-763$.

12. Levin B, Thompson JL, Chakraborty B, Levy G, MacArthur R, Haley EC. Statistical aspects of the TNK-S2B trial of tenecteplase versus alteplase in acute ischemic stroke: an efficient, dose-adaptive, seamless Phase II/III design. Clin Trials. 2011;8:398-407.

13. Hacke W, Furlan AJ, Al-Rawi Y, et al. Intravenous desmoteplase in patients with acute ischaemic stroke selected by MRI perfusion-diffusion weighted imaging or perfusion CT (DIAS-2): a prospective, randomised, double-blind, placebo-controlled study. Lancet Neurol. 2009;8: 141-150.

14. Hacke W, Albers G, Al-Rawi Y, et al. The Desmoteplase in Acute Ischemic Stroke Trial (DIAS): a phase II MRI-based 9-hour window acute stroke thrombolysis trial with intravenous desmoteplase. Stroke. 2005;36:66-73

15. del Zoppo GJ, Poeck K, Pessin MS, et al. Recombinant tissue plasminogen activator in acute thrombotic and embolic stroke. Ann Neurol. 1992;32:78-86.

16. Brott TG, Haley EC Jr, Levy DE, et al. Urgent therapy for stroke. Part I. Pilot study of tissue plasminogen activator administered within 90 minutes. Stroke. 1992;23:632-640.

17. Haley EC Jr, Levy DE, Brott TG, et al. Urgent therapy for stroke. Part II. Pilot study of tissue plasminogen activator administered 91-180 minutes from onset. Stroke. 1992;23:641-645.

18. Mori E, Yoneda Y, Tabuchi M, et al. Intravenous recombinant tissue plasminogen activator in acute carotid artery territory stroke. Neurology. 1992;42:976-982.

19. Clark WM, Albers GW, Madden KP, Hamilton S. The rtPA (alteplase) 0- to 6-hour acute stroke trial, part A (A0276g): results of a double-blind, placebo-controlled, multicenter study. Thromblytic therapy in acute ischemic stroke study investigators. Stroke. 2000;31: $811-816$.

20. Hacke W, Kaste M, Fieschi C, et al. Intravenous thrombolysis with recombinant tissue plasminogen activator for acute hemispheric stroke. The European Cooperative Acute Stroke Study (ECASS). JAMA. 1995;274: 1017-1025.

21. Brott T, Adams HP Jr, Olinger CP, et al. Measurements of acute cerebral infarction: a clinical examination scale. Stroke. 1989;20:864-870.

22. Brown DL, Johnston KC, Wagner DP, Haley EC Jr. Predicting major neurological improvement with intravenous recombinant tissue plasminogen activator treatment of stroke. Stroke. 2004;35:147-150.

23. Haley EC Jr, Lewandowski C, Tilley BC. Myths regarding the NINDS rt-PA Stroke Trial: setting the record straight. Ann Emerg Med. 1997;30:676-682.

24. Donnan GA, Davis SM, Chambers BR, et al. Streptokinase for acute ischemic stroke with relationship to time of administration: Australian Streptokinase (ASK) Trial Study Group. JAMA. 1996;276:961-966.
25. Horton R. MAST-I: agreeing to disagree. Multicentre Acute Stroke Trial - Italy Group. Lancet. 1995;346:1504.

26. Albers GW, Clark WM, Madden KP, Hamilton SA. ATLANTIS trial: results for patients treated within 3 hours of stroke onset. Alteplase Thrombolysis for Acute Noninterventional Therapy in Ischemic Stroke. Stroke. 2002;33:493-495.

27. Hacke W, Bluhmki E, Steiner T, et al. Dichotomized efficacy end points and global end-point analysis applied to the ECASS intention-to-treat data set: post hoc analysis of ECASS I. Stroke. 1998;29:2073-2075.

28. Wardlaw JM, Murray V, Berge E, Del Zoppo GJ. Thrombolysis for acute ischaemic stroke. Cochrane Database Syst Rev. 2009;(4): CD000213.

29. Hacke W, Kaste M, Fieschi C, et al. Randomised double-blind placebocontrolled trial of thrombolytic therapy with intravenous alteplase in acute ischaemic stroke (ECASS II). Second European-Australasian Acute Stroke Study Investigators. Lancet. 1998;352:1245-1251.

30. Ringleb PA, Schellinger PD, Schranz C, Hacke W. Thrombolytic therapy within 3 to 6 hours after onset of ischemic stroke: useful or harmful? Stroke. 2002;33:1437-1441.

31. Ma H, Parsons MW, Christensen S, et al. A multicentre, randomized, double-blinded, placebo-controlled Phase III study to investigate EXtending the time for Thrombolysis in Emergency Neurological Deficits (EXTEND). Int J Stroke. 2012;7:74-80.

32. Hacke W, Donnan G, Fieschi C, et al. Association of outcome with early stroke treatment: pooled analysis of ATLANTIS, ECASS, and NINDS rt-PA stroke trials. Lancet. 2004;363:768-774.

33. Hacke W, Kaste M, Bluhmki E, et al. Thrombolysis with alteplase 3 to 4.5 hours after acute ischemic stroke. $N$ Engl J Med. 2008;359: 1317-1329.

34. Jauch EC, Saver JL, Adams HP Jr, et al. Guidelines for the early management of patients with acute ischemic stroke: a guideline for healthcare professionals from the American Heart Association/American Stroke Association. Stroke. 2013;44:870-947.

35. Baron JC, von Kummer R, del Zoppo GJ. Treatment of acute ischemic stroke. Challenging the concept of a rigid and universal time window. Stroke. 1995;26:2219-2221.

36. Azzimondi G, Bassein L, Fiorani L, et al. Variables associated with hospital arrival time after stroke: effect of delay on the clinical efficiency of early treatment. Stroke. 1997;28:537-542.

37. Levy DE, Brott TG, Haley EC Jr, et al. Factors related to intracranial hematoma formation in patients receiving tissue-type plasminogen activator for acute ischemic stroke. Stroke. 1994;25:291-297.

38. Marler JR, Tilley BC, Lu M, et al. Early stroke treatment associated with better outcome: the NINDS rt-PA stroke study. Neurology. 2000;55:1649-1655.

39. Saver JL. Time is brain - quantified. Stroke. 2006;37:263-266.

40. Saver JL, Fonarow GC, Smith EE, et al. Time to treatment with intravenous tissue plasminogen activator and outcome from acute ischemic stroke. JAMA. 2013;309:2480-2488.

41. Fonarow GC, Smith EE, Saver JL, et al. Timeliness of tissue-type plasminogen activator therapy in acute ischemic stroke: patient characteristics, hospital factors, and outcomes associated with door-to-needle times within 60 minutes. Circulation. 2011;123:750-758.

42. Liman TG, Winter B, Waldschmidt C, et al. Telestroke ambulances in prehospital stroke management: concept and pilot feasibility study. Stroke. 2012;43:2086-2090.

43. Meretoja A, Strbian D, Mustanoja S, Tatlisumak T, Lindsberg PJ, Kaste M. Reducing in-hospital delay to 20 minutes in stroke thrombolysis. Neurology. 2012;79:306-313.

44. O'Gara PT, Kushner FG, Ascheim DD, et al. 2013 ACCF/AHA guideline for the management of ST-elevation myocardial infarction: a report of the American College of Cardiology Foundation/American Heart Association Task Force on Practice Guidelines. Circulation. 2013;127:e362-e425.

45. Hill MD, Lye T, Moss H, et al. Hemi-orolingual angioedema and ace inhibition after alteplase treatment of stroke. Neurology. 2003;60:1525-1527. 
46. Pessin MS, Del Zoppo GJ, Estol CJ. Thrombolytic agents in the treatment of stroke. Clin Neuropharmacol. 1990;13:271-289.

47. Trouillas P, von Kummer R. Classification and pathogenesis of cerebral hemorrhages after thrombolysis in ischemic stroke. Stroke. 2006;37:556-561.

48. Derex L, Nighoghossian N. Intracerebral haemorrhage after thrombolysis for acute ischaemic stroke: an update. J Neurol Neurosurg Psychiatry. 2008;79:1093-1099.

49. Clark WM, Wissman S, Albers GW, Jhamandas JH, Madden KP, Hamilton S. Recombinant tissue-type plasminogen activator (Alteplase) for ischemic stroke 3 to 5 hours after symptom onset. The ATLANTIS Study: a randomized controlled trial. Alteplase Thrombolysis for Acute Noninterventional Therapy in Ischemic Stroke. JAMA. 1999;282:2019-2026.

50. Larrue V, von Kummer RR, Muller A, Bluhmki E. Risk factors for severe hemorrhagic transformation in ischemic stroke patients treated with recombinant tissue plasminogen activator: a secondary analysis of the European-Australasian Acute Stroke Study (ECASS II). Stroke. 2001:32:438-441.

51. Hacke W, Brott T, Caplan L, et al. Thrombolysis in acute ischemic stroke: controlled trials and clinical experience. Neurology. 1999;53: S3-S14.

52. Wahlgren N, Ahmed N, Eriksson N, et al. Multivariable analysis of outcome predictors and adjustment of main outcome results to baseline data profile in randomized controlled trials: Safe Implementation of Thrombolysis in Stroke-MOnitoring STudy (SITS-MOST). Stroke. 2008;39:3316-3322.

53. Strbian D, Sairanen T, Meretoja A, et al. Patient outcomes from symptomatic intracerebral hemorrhage after stroke thrombolysis. Neurology. 2011;77:341-348.

54. Southerland AM, Malik S, Johnston KC. Symptomatic ICH and outcomes in patients after IV tPA: a business of risk or risky business? Neurology. 2011;77:315-316.

55. Demchuk AM, Morgenstern LB, Krieger DW, et al. Serum glucose level and diabetes predict tissue plasminogen activator-related intracerebral hemorrhage in acute ischemic stroke. Stroke. 1999;30:34-39.

56. Tanne D, Kasner SE, Demchuk AM, et al. Markers of increased risk of intracerebral hemorrhage after intravenous recombinant tissue plasminogen activator therapy for acute ischemic stroke in clinical practice: the Multicenter rt-PA Stroke Survey. Circulation. 2002;105 1679-1685.

57. Saposnik G, Di Legge S, Webster F, Hachinski V. Predictors of major neurologic improvement after thrombolysis in acute stroke. Neurology. 2005;65:1169-1174.

58. Bateman BT, Schumacher HC, Boden-Albala B, et al. Factors associated with in-hospital mortality after administration of thrombolysis in acute ischemic stroke patients: an analysis of the nationwide inpatient sample 1999 to 2002. Stroke. 2006;37:440-446.

59. Mazya M, Egido JA, Ford GA, et al. Predicting the risk of symptomatic intracerebral hemorrhage in ischemic stroke treated with intravenous alteplase: safe implementation of treatments in stroke (SITS) symptomatic intracerebral hemorrhage risk score. Stroke. 2012;43: 1524-1531.

60. Generalized efficacy of t-PA for acute stroke. Subgroup analysis of the NINDS t-PA Stroke Trial. Stroke. 1997;28:2119-2125.

61. Saver JL. Deriving number-needed-to-treat and number-needed-toharm from the SAINT I trial results. Stroke. 2007;38:257; author reply 258.

62. Saver JL, Gornbein J, Grotta J, et al. Number needed to treat to benefit and to harm for intravenous tissue plasminogen activator therapy in the 3- to 4.5-hour window: joint outcome table analysis of the ECASS 3 trial. Stroke. 2009;40:2433-2437.

63. Rabinstein A, Rundek T. Prediction of outcome after ischemic stroke: the value of clinical scores. Neurology. 2013;80:15-16.

64. Davalos A, Blanco M, Pedraza S, et al. The clinical-DWI mismatch a new diagnostic approach to the brain tissue at risk of infarction. Neurology. 2004;62:2187-2192.
65. Lansberg MG, Thijs VN, Hamilton S, et al. Evaluation of the clinicaldiffusion and perfusion-diffusion mismatch models in DEFUSE. Stroke. 2007:38:1826-1830.

66. Kidwell CS, Jahan R, Saver JL. Endovascular treatment for acute ischemic stroke. N Engl J Med. 2013;368:2434-2435.

67. Davis SM, Donnan GA, Parsons MW, et al. Effects of alteplase beyond $3 \mathrm{~h}$ after stroke in the Echoplanar Imaging Thrombolytic Evaluation Trial (EPITHET): a placebo-controlled randomised trial. Lancet Neurol. 2008;7:299-309.

68. Barber PA, Zhang J, Demchuk AM, Hill MD, Buchan AM. Why are stroke patients excluded from tPA therapy? An analysis of patient eligibility. Neurology. 2001;56:1015-1020.

69. Katzan IL, Hammer MD, Hixson ED, Furlan AJ, Abou-Chebl A, Nadzam DM. Utilization of intravenous tissue plasminogen activator for acute ischemic stroke. Arch Neurol. 2004;61:346-350.

70. Cocho D, Belvis R, Marti-Fabregas J, et al. Reasons for exclusion from thrombolytic therapy following acute ischemic stroke. Neurology. 2005;64:719-720.

71. Kleindorfer D, Kissela B, Schneider A, et al. Eligibility for recombinant tissue plasminogen activator in acute ischemic stroke: a populationbased study. Stroke. 2004;35:e27-e29.

72. Smith EE, Fonarow GC, Reeves MJ, et al. Outcomes in mild or rapidly improving stroke not treated with intravenous recombinant tissue-type plasminogen activator: findings from Get With The Guidelines - Stroke. Stroke. 2011;42:3110-3115.

73. Rajajee V, Kidwell C, Starkman S, et al. Early MRI and outcomes of untreated patients with mild or improving ischemic stroke. Neurology. 2006;67:980-984.

74. Nedeltchev K, Schwegler B, Haefeli T, et al. Outcome of stroke with mild or rapidly improving symptoms. Stroke. 2007;38:2531-2535.

75. Baumann CR, Baumgartner RW, Gandjour J, von Budingen HC, Siegel AM, Georgiadis D. Good outcomes in ischemic stroke patients treated with intravenous thrombolysis despite regressing neurological symptoms. Stroke. 2006;37:1332-1333.

76. Kohrmann M, Nowe T, Huttner HB, et al. Safety and outcome after thrombolysis in stroke patients with mild symptoms. Cerebrovasc Dis. 2009;27:160-166.

77. Hassan AE, Hassanzadeh B, Tohidi V, Kirmani JF. Very mild stroke patients benefit from intravenous tissue plasminogen activator without increase of intracranial hemorrhage. South Med J. 2010;103:398-402.

78. Bluhmki E, Chamorro A, Davalos A, et al. Stroke treatment with alteplase given 3.0-4.5 h after onset of acute ischaemic stroke (ECASS III): additional outcomes and subgroup analysis of a randomised controlled trial. Lancet Neurol. 2009;8:1095-1102.

79. Saver JL. Improving reperfusion therapy for acute ischaemic stroke. J Thromb Haemost. 2011;9 Suppl 1:333-343.

80. Khatri P, Conaway MR, Johnston KC. Ninety-day outcome rates of a prospective cohort of consecutive patients with mild ischemic stroke. Stroke. 2012;43:560-562.

81. Marini C, Baldassarre M, Russo T, et al. Burden of first-ever ischemic stroke in the oldest old: evidence from a population-based study. Neurology. 2004;62:77-81.

82. Derex L, Nighoghossian N. Thrombolysis, stroke-unit admission and early rehabilitation in elderly patients. Nat Rev Neurol. 2009;5: 506-511.

83. Kammersgaard LP, Jorgensen HS, Reith J, Nakayama H, Pedersen PM, Olsen TS. Short- and long-term prognosis for very old stroke patients. The Copenhagen Stroke Study. Age Ageing. 2004;33:149-154.

84. Sloan MA, Price TR, Petito CK, et al. Clinical features and pathogenesis of intracerebral hemorrhage after rt-PA and heparin therapy for acute myocardial infarction: the Thrombolysis in Myocardial Infarction (TIMI) II Pilot and Randomized Clinical Trial combined experience. Neurology. 1995;45:649-658.

85. Greenberg SM, Vonsattel JP. Diagnosis of cerebral amyloid angiopathy. Sensitivity and specificity of cortical biopsy. Stroke. 1997;28:1418-1422. 
86. Haley KE, Greenberg SM, Gurol ME. Cerebral microbleeds and macrobleeds: should they influence our recommendations for antithrombotic therapies? Curr Cardiol Rep. 2013;15:425.

87. Tanne D, Gorman MJ, Bates VE, et al. Intravenous tissue plasminogen activator for acute ischemic stroke in patients aged 80 years and older: the tPA stroke survey experience. Stroke. 2000;31:370-375.

88. Meretoja A, Putaala J, Tatlisumak T, et al. Off-label thrombolysis is not associated with poor outcome in patients with stroke. Stroke. 2010;41: 1450-1458.

89. Sylaja PN, Cote R, Buchan AM, Hill MD. Thrombolysis in patients older than 80 years with acute ischaemic stroke: Canadian alteplase for stroke effectiveness study. J Neurol Neurosurg Psychiatry. 2006;77: 826-829.

90. van Oostenbrugge RJ, Hupperts RM, Lodder J. Thrombolysis for acute stroke with special emphasis on the very old: experience from a single Dutch centre. J Neurol Neurosurg Psychiatry. 2006;77:375-377.

91. Engelter ST, Bonati LH, Lyrer PA. Intravenous thrombolysis in stroke patients of $>$ or $=80$ versus $<80$ years of age - a systematic review across cohort studies. Age Ageing. 2006;35:572-580.

92. Mouradian MS, Senthilselvan A, Jickling G, et al. Intravenous rt-PA for acute stroke: comparing its effectiveness in younger and older patients. J Neurol Neurosurg Psychiatry. 2005;76:1234-1237.

93. Mishra NK, Ahmed N, Andersen G, et al. Thrombolysis in very elderly people: controlled comparison of SITS International Stroke Thrombolysis Registry and Virtual International Stroke Trials Archive. BMJ. 2010;341:c6046.

94. Sandercock P, Wardlaw JM, Lindley RI, et al. The benefits and harms of intravenous thrombolysis with recombinant tissue plasminogen activator within $6 \mathrm{~h}$ of acute ischaemic stroke (the Third International Stroke Trial [IST-3]): a randomised controlled trial. Lancet. 2012;379: 2352-2363.

95. Howard G, Goff DC. Population shifts and the future of stroke: forecasts of the future burden of stroke. Ann N Y Acad Sci. 2012;1268: 14-20.

96. Rudolf J, Tsivgoulis G, Deretzi G, et al. Feasibility and safety of intravenous thrombolysis for acute ischaemic stroke in northern Greece. Int J Stroke. 2011;6:91-92.

97. Chernyshev OY, Martin-Schild S, Albright KC, et al. Safety of tPA in stroke mimics and neuroimaging-negative cerebral ischemia. Neurology. 2010;74:1340-1345.

98. Winkler DT, Fluri F, Fuhr P, et al. Thrombolysis in stroke mimics: frequency, clinical characteristics, and outcome. Stroke. 2009;40: $1522-1525$.

99. Scott PA, Silbergleit R. Misdiagnosis of stroke in tissue plasminogen activator-treated patients: characteristics and outcomes. Ann Emerg Med. 2003;42:611-618.

100. Tsivgoulis G, Alexandrov AV, Chang J, et al. Safety and outcomes of intravenous thrombolysis in stroke mimics: a 6-year, single-care center study and a pooled analysis of reported series. Stroke. 2011;42: 1771-1774.

101. Guerrero WR, Savitz SI. Tissue-type plasminogen activator for stroke mimics: continuing to be swift rather than delaying treatment to be sure. Stroke. 2013;44:1213-1214.

102. Hand PJ, Kwan J, Lindley RI, Dennis MS, Wardlaw JM. Distinguishing between stroke and mimic at the bedside: the brain attack study. Stroke. 2006;37:769-775.

103. Libman RB, Wirkowski E, Alvir J, Rao TH. Conditions that mimic stroke in the emergency department. Implications for acute stroke trials. Arch Neurol. 1995;52:1119-1122.

104. Anderson CS, Jamrozik KD, Burvill PW, Chakera TM, Johnson GA, Stewart-Wynne EG. Ascertaining the true incidence of stroke: experience from the Perth Community Stroke Study, 1989-1990. Med J Aust. 1993;158:80-84.

105. Ellekjaer H, Holmen J, Indredavik B, Terent A. Epidemiology of stroke in Innherred, Norway, 1994 to 1996. Incidence and 30-day case-fatality rate. Stroke. 1997;28:2180-2184.
106. Artto V, Putaala J, Strbian D, et al. Stroke mimics and intravenous thrombolysis. Ann Emerg Med. 2012;59:27-32.

107. Zinkstok SM, Engelter ST, Gensicke H, et al. Safety of thrombolysis in stroke mimics: results from a multicenter cohort study. Stroke. 2013;44:1080-1084.

108. Marti-Fabregas J, Bravo Y, Cocho D, et al. Frequency and predictors of symptomatic intracerebral hemorrhage in patients with ischemic stroke treated with recombinant tissue plasminogen activator outside clinical trials. Cerebrovasc Dis. 2007;23:85-90.

109. Hill MD, Buchan AM. Thrombolysis for acute ischemic stroke: results of the Canadian Alteplase for Stroke Effectiveness Study. CMAJ. 2005;172:1307-1312.

110. Meschia JF, Williams LS, Fleck JD, Bruno A, Biller J. Views on the use of tissue plasminogen activator in acute ischemic stroke: a state-wide survey among neurologists and emergency medicine physicians in Indiana. J Stroke Cerebrovasc Dis. 1999;8: 207-210.

111. Brown DL, Barsan WG, Lisabeth LD, Gallery ME, Morgenstern LB. Survey of emergency physicians about recombinant tissue plasminogen activator for acute ischemic stroke. Ann Emerg Med. 2005;46:56-60.

112. Shamy MC, Jaigobin CS. The complexities of acute stroke decision-making: a survey of neurologists. Neurology. 2013;81: 1130-1133.

113. Weintraub MI. Thrombolysis (tissue plasminogen activator) in stroke: a medicolegal quagmire. Stroke. 2006;37:1917-1922.

114. Liang BA, Zivin JA. Empirical characteristics of litigation involving tissue plasminogen activator and ischemic stroke. Ann Emerg Med. 2008;52:160-164.

115. Cucchiara B, Tanne D, Levine SR, Demchuk AM, Kasner S. A risk score to predict intracranial hemorrhage after recombinant tissue plasminogen activator for acute ischemic stroke. J Stroke Cerebrovasc Dis. 2008;17:331-333.

116. Lou M, Safdar A, Mehdiratta M, et al. The HAT score: a simple grading scale for predicting hemorrhage after thrombolysis. Neurology. 2008;71:1417-1423.

117. Menon BK, Saver JL, Prabhakaran S, et al. Risk score for intracranial hemorrhage in patients with acute ischemic stroke treated with intravenous tissue-type plasminogen activator. Stroke. 2012;43: 2293-2299.

118. Strbian D, Engelter S, Michel P, et al. Symptomatic intracranial hemorrhage after stroke thrombolysis: the SEDAN score. Ann Neurol. 2012;71:634-641.

119. Strbian D, Meretoja A, Ahlhelm FJ, et al. Predicting outcome of IV thrombolysis-treated ischemic stroke patients: the DRAGON score. Neurology. 2012;78:427-432.

120. Saposnik G, Guzik AK, Reeves M, Ovbiagele B, Johnston SC. Stroke prognostication using age and NIH Stroke Scale: SPAN-100. Neurology. 2013;80:21-28.

121. Saposnik G, Fang J, Kapral MK, et al. The iScore predicts effectiveness of thrombolytic therapy for acute ischemic stroke. Stroke. 2012;43:1315-1322.

122. Kent DM, Selker HP, Ruthazer R, Bluhmki E, Hacke W. The stroke-thrombolytic predictive instrument: a predictive instrument for intravenous thrombolysis in acute ischemic stroke. Stroke. 2006;37:2957-2962.

123. Ntaios G, Faouzi M, Ferrari J, Lang W, Vemmos K, Michel P. An integer-based score to predict functional outcome in acute ischemic stroke: the ASTRAL score. Neurology. 2012;78:1916-1922.

124. Chiu D, Krieger D, Villar-Cordova C, et al. Intravenous tissue plasminogen activator for acute ischemic stroke: feasibility, safety, and efficacy in the first year of clinical practice. Stroke. 1998;29: $18-22$.

125. Grond M, Stenzel C, Schmulling S, et al. Early intravenous thrombolysis for acute ischemic stroke in a community-based approach. Stroke. 1998;29:1544-1549. 
126. Katzan IL, Furlan AJ, Lloyd LE, et al. Use of tissue-type plasminogen activator for acute ischemic stroke: the Cleveland area experience. JAMA. 2000;283:1151-1158.

127. Wang SL, Pan WH, Lee MC, Cheng SP, Chang MC. Predictors of survival among elders suffering strokes in Taiwan: observation from a nationally representative sample. Stroke. 2000;31:2354-2360.

128. Albers GW, Bates VE, Clark WM, Bell R, Verro P, Hamilton SA. Intravenous tissue-type plasminogen activator for treatment of acute stroke: the Standard Treatment with Alteplase to Reverse Stroke (STARS) study. JAMA. 2000;283:1145-1150.

129. Lopez-Yunez AM, Bruno A, Williams LS, Yilmaz E, Zurru C, Biller J. Protocol violations in community-based rTPA stroke treatment are associated with symptomatic intracerebral hemorrhage. Stroke. 2001;32:12-16.
130. Grotta JC, Burgin WS, El-Mitwalli A, et al. Intravenous tissue-type plasminogen activator therapy for ischemic stroke: Houston experience 1996 to 2000. Arch Neurol. 2001;58:2009-2013.

131. Koennecke HC, Nohr R, Leistner S, Marx P. Intravenous tPA for ischemic stroke team performance over time, safety, and efficacy in a single-center, 2-year experience. Stroke. 2001;32:1074-1078.

132. Bravata DM, Kim N, Concato J, Krumholz HM, Brass LM. Thrombolysis for acute stroke in routine clinical practice. Arch Intern Med. 2002;162:1994-2001.

133. Katzan IL, Hammer MD, Furlan AJ, Hixson ED, Nadzam DM. Quality improvement and tissue-type plasminogen activator for acute ischemic stroke: a Cleveland update. Stroke. 2003;34:799-800.
Vascular Health and Risk Management

\section{Publish your work in this journal}

Vascular Health and Risk Management is an international, peerreviewed journal of therapeutics and risk management, focusing on concise rapid reporting of clinical studies on the processes involved in the maintenance of vascular health; the monitoring, prevention and treatment of vascular disease and its sequelae; and the involvement of

\section{Dovepress}

metabolic disorders, particularly diabetes. This journal is indexed on PubMed Central and MedLine. The manuscript management system is completely online and includes a very quick and fair peer-review system, which is all easy to use. Visit http://www.dovepress.com/ testimonials.php to read real quotes from published authors.

Submit your manuscript here: http://www.dovepress.com/vascular-health-and-risk-management-journal 